\title{
Complete Spontaneous Thrombosis and Recanalization of a Ruptured Posterior Cerebral Artery Aneurysm
}

\author{
Rüptüre Posterior Serebral Arter Anevrizmasinun Tam Spontan \\ Trombozu ve Rekanalizasyonu
}

Du WEI ${ }^{1,2}$, Zhou JINGRU ${ }^{2}$, Fan CUNGANG ${ }^{2}$, Xue YAKE ${ }^{1}$, Wang DONGLIANG ${ }^{2}$, Wei ZHENGMAO ${ }^{2}$, Wei XINTING ${ }^{1}$, Zhang QINGJUN ${ }^{2}$

${ }^{1}$ The First Affiliated Hospital of Zhengzhou University, Department of Neurosurgery, Zhengzhou, Henan, China

${ }^{2}$ Peking University People's Hospital, Department of Neurosurgery, Beijing, China

Corresponding Author: Zhang QINGJUN / E-mail: zhangqjpku@126.com

\begin{abstract}
Complete spontaneous thrombosis followed by recanalization of non-giant aneurysms is a rare event that can be discovered incidentally on advanced neural images. In this case report, the authors described a woman who presented with subarachnoid hemorrhage (SAH) and left posterior cerebral artery (PCA) territory ischemic stroke. Cerebral angiography revealed a left PCA aneurysm at the P1-P2 junction. The patient received conservative treatment and repeated cerebral angiography 4 weeks later demonstrated the disappeared aneurysm. Subsequent magnetic resonance imaging (MRI) and contrast-enhanced computed tomography (CT) demonstrated the totally thrombosed aneurysm with hydrocephalus. Ventriculo-peritoneal shunt surgery for hydrocephalus was performed and the patient noted a great improvement of the neurological deficit. Follow-up contrast-enhanced CT after 10 weeks revealed recurrence of the aneurysm. This case provides insight into the natural dynamic process of intracranial aneurysm, and a complete thrombosed aneurysm has the potential for recanalization.
\end{abstract}

KEYWORDS: Intracranial aneurysm, Subarachnoid hemorrhage, Spontaneous thrombosis, Recanalization

öz

Dev olmayan anevrizmalarda rekanalizasyonla birlikte tam spontan tromboz nadirdir ve gelişmiş nöral görüntülerde tesadüfen bulunabilir. $\mathrm{Bu}$ olgu raporunda yazarlar subaraknoid kanama (SAK) ve sol posterior serebral arter (PSA) bölgesinde iskemik inmeyle gelen bir hastayı sunmaktadır. Serebral anjiyografi P1-P2 bileşkesinde bir sol PSA anevrizması göstermiştir. Hastaya konservatif tedavi verilmiş ve 4 hafta sonra tekrarlanan serebral anjiyografi anevrizmanın kaybolduğunu ortaya koymuştur. Daha sonraki manyetik rezonans görüntüleme (MRG) ve kontrastlı bilgisayarlı tomografi (BT) total tromboze olmuş anevrizma ve hidrosefali göstermiştir. Hidrosefali için ventriküloperitoneal şant cerrahisi yapılmış ve hastanın nörolojik defisinde büyük bir düzelme görmüştür. 10 hafta sonra takip kontrastı BT anevrizmanın tekrarladığını göstermiştir. Bu olgu bir intrakraniyal anevrizmanın doğal dinamik süreci konusunda bilgi sağlamaktadır ve tam trombozlu bir anevrizmada rekanalizasyon potansiyeli mevcuttur.

ANAHTAR SÖZCÜKLER: Intrakraniyal anevrizma, Subaraknoid kanama, Spontan tromboz, Rekanalizasyon

\section{INTRODUCTION}

Cerebral aneurysm is the principle cause of nontraumatic subarachnoid hemorrhage due to rupture. Spontaneous thrombosis of a giant intracranial aneurysm is not an uncommon event and could be followed by a parent artery thrombosis, ischemic stroke and focal neurological deficits $(10,2)$. There are many reports of spontaneous thrombosis of giant aneurysms, and various factors have been discussed in literature. These partially or completely thrombosed aneurysms are considered unstable lesions that may either grow, compress, recanalize or give rise to rupture events (3). However, in non-giant aneurysms, the process of complete thrombosis and recanalization has been rarely reported and in general, is poorly understood.
We describe a rare case of recanalization of a totally thrombosed non-giant ruptured posterior cerebral artery aneurysm and review the possible pathogenic mechanisms.

\section{CASE REPORT}

A 36-year-old woman was admitted to a local hospital with sudden bursting headache and deterioration of consciousness. Until her present illness, there was no past medical history and no noticeable physical anomalies. Urgent computed tomography (CT) scan of brain demonstrated diffuse subarachnoid hemorrhage (SAH) with cerebral infarction in the left posterior cerebral artery (PCA) territory (Figure $1 A, B)$. Cerebral angiography revealed a left PCA aneurysm arising from the $P 1-P 2$ junction with vasospasm of 

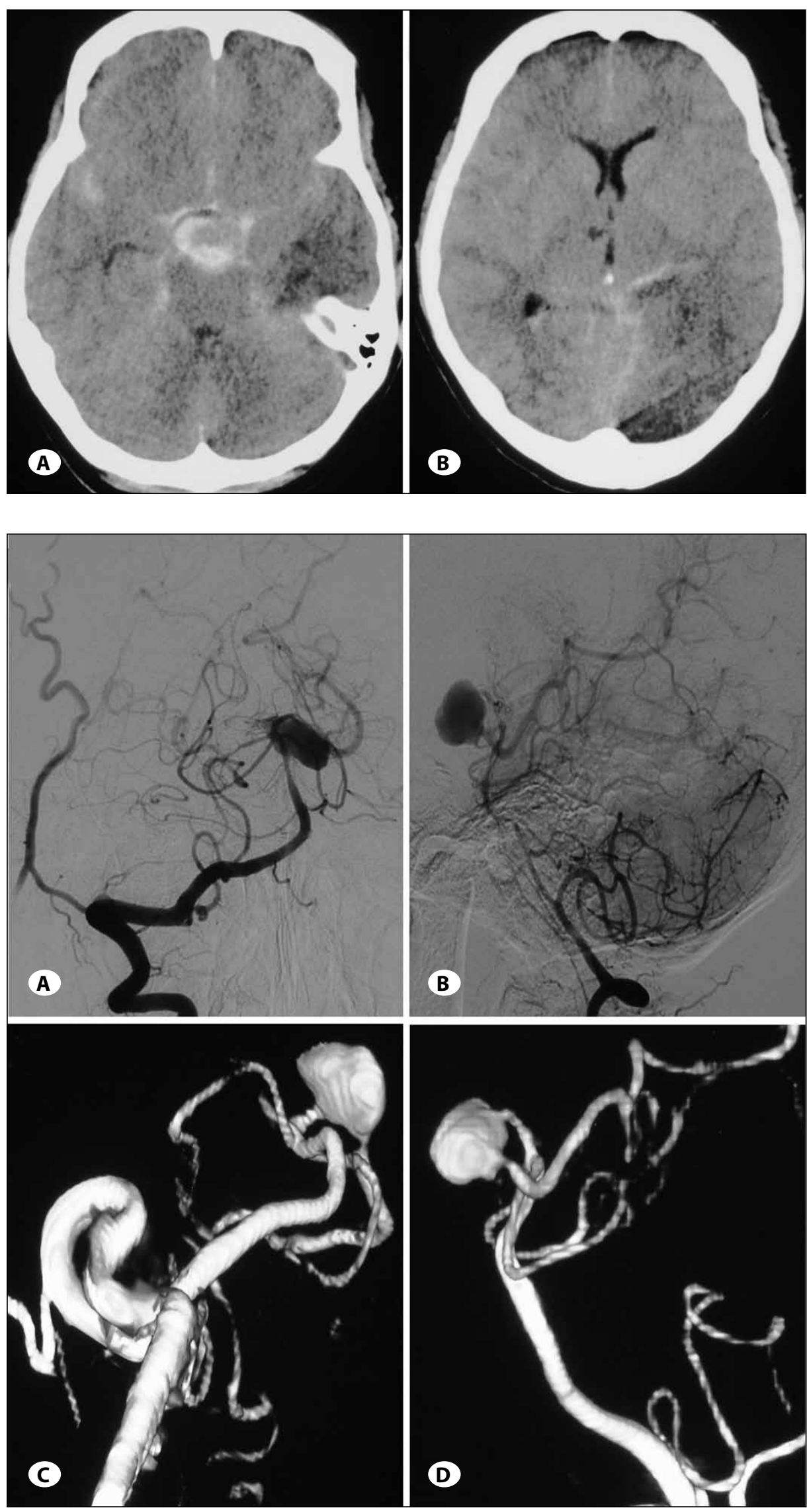

Figure 1: Axial plain CT scans of brain (A, B) on admission demonstrated subarachnoid hemorrhage $(\mathrm{SAH})$ with the hypodensity in the left posterior cerebral artery (PCA) territory.

Figure 2: Anteroposterior angiogram (A), lateral angiogram (B) and $3 D$ reconstruction of dynamic DSA (C, D) showed a left PCA aneurysm arising from the P1$P 2$ junction with vasospasm of the parent artery. 


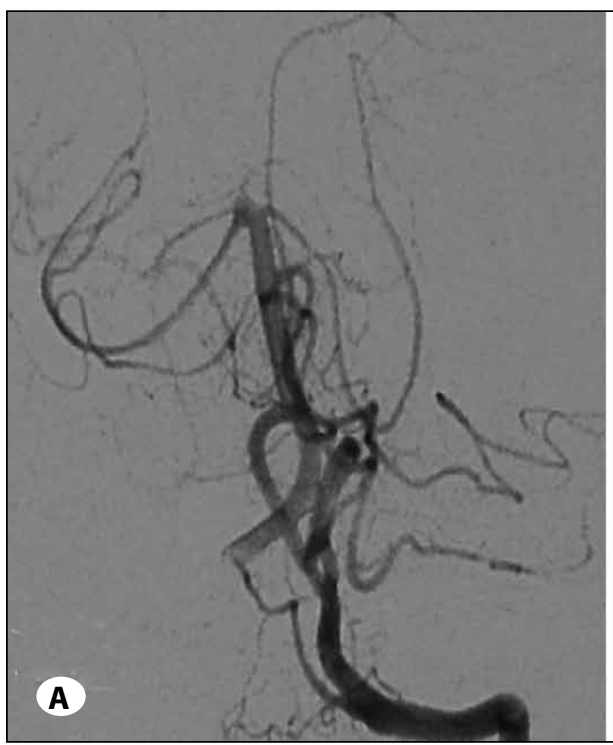

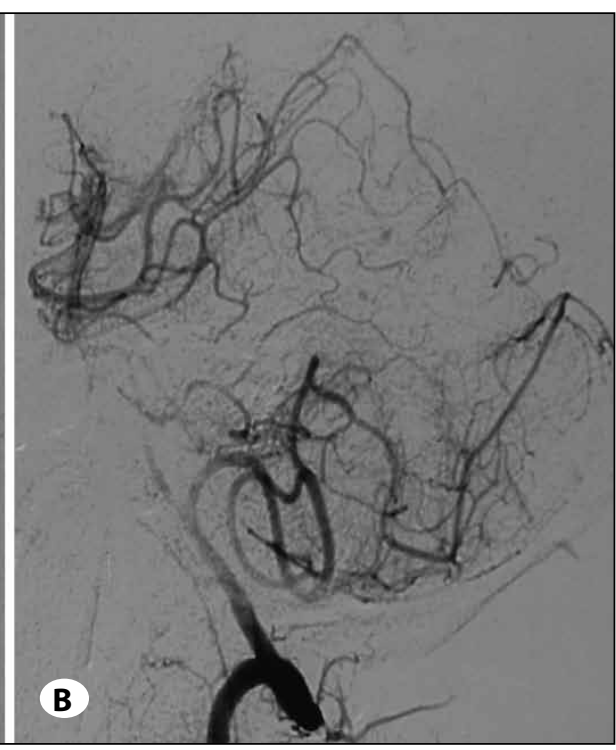

Figure 3: Anteroposterior (A) and lateral (B) angiograms taken 4 weeks later showed the aneurysm disappeared completely. the parent artery (Figure 2A-D). The patient was treated with non-steroidal anti-inflammation and anticonvulsant drugs, and her level of consciousness improved. Four weeks later, this patient was transferred to our neurosurgical department for further treatment. At the moment of the admittance, she exhibited orientation disturbance, right hemiparesis and right homonymous hemianopsia. Repeated angiography was performed on the day of transfer that failed to show the aneurysm (Figure 3A,B). Sequential head magnetic resonance imaging (MRI) and contrast-enhanced CT demonstrated the complete thrombosed aneurysm associated with left PCA territory infarction and hydrocephalus (Figure 4A-D). These findings were considered to be complete spontaneous thrombosis of the aneurysm and microsurgical clipping of the aneurysm was deferred. The patient underwent a ventriculoperitoneal shunt because of hydrocephalus. Thereafter, she was noted a great improvement of neurological deficit and was discharged from our hospital.

Follow-up contrast-enhanced CT after 10 weeks in the district hospital demonstrated recanalization of the aneurysm (Figure $5 A, B)$. Considering the recanalized aneurysm may rerupture, the need of surgical clipping or endovascular treatment was strongly recommended. However, the suggestion was refused and the patient is receiving rehabilitation therapy.

\section{DISCUSSION}

Spontaneous thrombosis of ruptured aneurysms is a well-documented phenomenon in the natural history of intracranial aneurysms. While it is more common in giant intracranial aneurysms, occurring in approximately $50 \%$ of cases, the occurrence of these phenomena in non-giant aneurysms has been rarely reported (9).

Various biophysical and dynamic factors have been suggested to influence the spontaneous thrombosis of intracranial aneurysms. The aneurismal volume to neck size ratio has been considered to be the mainly factor for thrombus formation because of hemodynamic disturbance (1). Intraluminal thrombosis may occur in aneurysms with a relatively small neck (8). In addition, other biophysiological factors such as increased blood coagulability, age of the aneurysm, hemodymanics in the parent artery, direct distortion of the parent artery by the aneurysmal sac, turbulent flow in aneurysms, endothelial damage and increased platelet aggregation have also been proposed $(2,1)$.

The angiographic procedure itself and contrast media used in angiography is another factor in spontaneous thrombosis of intracranial aneurysms. In our patient, follow-up angiogram after 4 weeks showed disappeared aneurysm. It is estimated that no more than $1 \%$ or $2 \%$ of ruptured aneurysms will show thrombosis completely on subsequent angiography (4). Although the relation between contrast media used and clotting mechanism has not been well understood, it is considered that both of non-ionic media and ionic media may cause thrombosis of aneurysms by platelet and red blood cell aggregation, slow flow due to partial obstruction induced by the catheter, endothelial injury or spasm of the parent artery (5).

It is also pointed out that an aneurysm may diminish in size or disappear completely after partial or complete temporary or permanent occlusion of the parent artery (2). In our case, clinical and imaging correlation provided evidence that the aneurysm could have thrombosed and had originated from occlusion of the parent artery of the aneurysm. The possible pathogenic mechanisms have been described as local extension of the luminal thrombi, retrograde development of a thrombus originating within the aneurysm or secondary to dislodgement of intra-aneurysm thrombus (7).

Although growth, recanalization, and hemorrhage of the thrombosed giant aneurysms are well described, similar events for non-giant aneurysms has been only rarely reported 

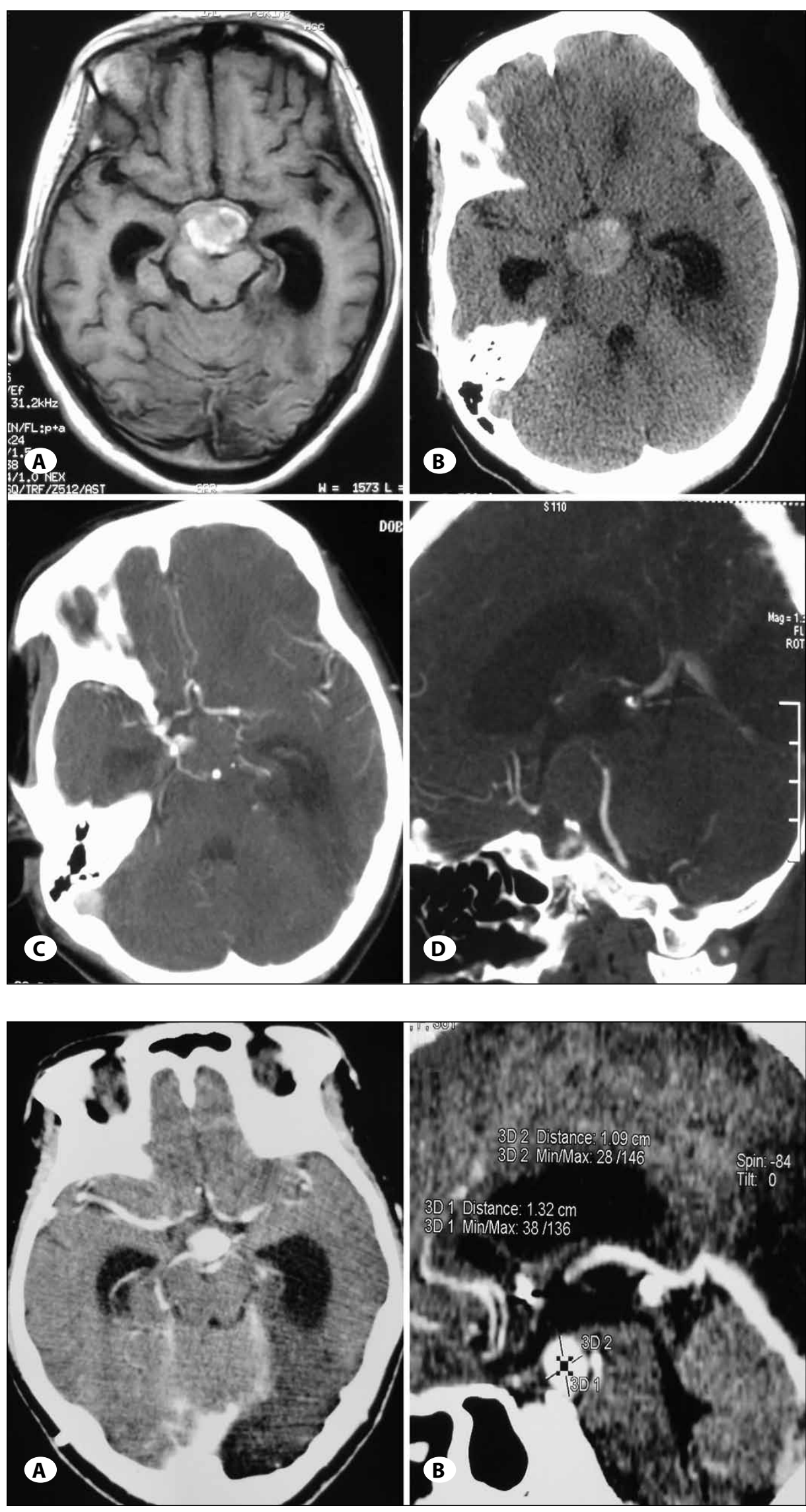

Figure 4: Axial MR image (A), plain CT scan (B), and enhanced CT scan (C, D) 4 weeks later indicated the thrombosed aneurysm (measuring approximately $20 \mathrm{~mm}$ in diameter) with a left PCA territory infarction and hydrocephalus.

Figure 5: Ten-week follow-up axial contrast-enhanced CT (A) and sagittal contrast-enhanced CT (B) showed reappearance of the aneurysm (measuring about $13 \times 11 \times 14 \mathrm{~mm})$. 
(6). The mechanism of recanalization of spontaneously thrombosed aneurysm is poorly understood with few literature reports. As Pritz reported, the thrombosed non-giant aneurysm behaved similar to a thrombosed giant aneurysm. Growth or recanalization of this type of non-giant aneurysm has been attributed to such possible reasons: hemorrhage into the aneurysm wall, clot retraction or bleeding into the thrombus itself (6).

The principal message of our study is that spontaneous aneurysmal thrombosis cannot per se always be considered a good or safe sign. Even a completely thrombosed non-giant aneurysms are unstable and has little prognostic significance, which should be taken carefully into consideration when discussing the therapeutic management.

\section{CONCLUSION}

The natural history of intracranial aneurysms is a dynamic process thought to be governed by delicate balance between thrombogenesis and thrombolysis. Spontaneous thrombosis of the aneurysms should be considered a possibility dynamic state. However, even when the angiographically occluded non-giant aneurysms may not predict a good outcome, there is still a risk of recanalization and rupture. Therefore, even a completely clotted, non-giant aneurysm can potentially be life threatening and requires vigilant monitoring.

\section{REFERENCES}

1. Brownlee RD, Tranmer BI, Sevick RJ, Karmy G, Curry BJ: Spontaneous thrombosis of an unruptured anterior communicating artery aneurysm. An unusual cause of ischemic stroke. Stroke 26:1945-1949, 1995
2. Cohen JE, Itshayek E, Gomori JM, Grigoriadis S, Raphaeli G, Spektor S, Rajz G: Spontaneous thrombosis of cerebral aneurysms presenting with ischemic stroke. J Neurol Sci 254: 95-98, 2007

3. Cohen JE, Rajz G, Umansky F, Spektor S: Thrombosis and recanalization of symptomatic nongiant saccular aneurysm. Neurol Res 25: 857-859, 2003

4. Edner G, Forster DM, Steiner L, Bergvall U: Spontaneous healing of intracranial aneurysms after subarachnoid hemorrhage. Case report. J Neurosurg 48: 450-454, 1978.

5. Gabelmann A, Haberstroh J, Weyrich G: Ionic and non-ionic contrast agent-mediated endothelial injury. Quantitative analysis of cell proliferation during endothelial repair. Acta Radiol 42:422-425, 2001

6. Pritz MB: Thrombosis, growth, recanalization, and rupture of a saccular, non-giant cerebral aneurysm. J Stroke Cerebrovasc Dis 17:158-160, 2008

7. Schaller B, Lyrer P: Focal neurological deficits following spontaneous thrombosis of unruptured giant aneurysms. Eur Neurol 47:175-182, 2002

8. Schubiger O, Valavanis A, Wichmann W: Growth-mechanism of giant intracranial aneurysms; demonstration by CT and MR imaging. Neuroradiology 29: 266-271, 1987

9. Whittle IR, Dorsch NW, Besser M: Spontaneous thrombosis in giant intracranial aneurysms. J Neurol Neurosurg Psychiatry 45:1040-1047, 1982

10. Whittle IR, Williams DB, Halmagyi GM, Besser M: Spontaneous thrombosis of a giant intracranial aneurysm and ipsilateral internal carotid artery: Case report. J Neurosurg 56:287-289, 1982 